\title{
Control of Power and Voltage of Solar Grid Connected
}

\author{
Boucetta Abd Allah*, Labed Djamel** \\ Department of Electrical Engineering, University of Constantine 1, Algeria
}

\begin{tabular}{l}
\hline Article Info \\
\hline Article history: \\
Received Jul 21, 2015 \\
Revised Oct 26, 2015 \\
Accepted Nov 10, 2015 \\
\hline
\end{tabular}

\section{Keyword:}

Grid-connected

Matlab/Simulink

Maximum power point

Photovoltaic

VOC

\begin{abstract}
Renewable energy is high on international agendas. Currently, gridconnected photovoltaic systems are a popular technology to convert solar energy into electricity. Control of power injected into the grid, maximum power point, high efficiency, and low total harmonic distortion of the currents injected into the grid are the requirements for inverter connection into the grid. Consequently, the performance of the inverters connected to the grid depends largely on the control strategy applied. In this paper the simulation and design of grid connected three phase photovoltaic system using Matlab/Simulink has examined. The proposed system consists photovoltaic panels, boost and inverter the PV system convert the sun irradiation into direct current, thereafter we have used a boost to track the maximum power point of the PV system, three-phase inverter and LC output filter. A VOC control strategy based on the phase shifting of the inverter output voltage with respect to the grid voltage. The proposed control strategy requires few hardware and computational resources. As a result, the inverter implementation is simple, and it becomes an attractive solution for low power grid connected applications.
\end{abstract}

Copyright (C) 2016 Institute of Advanced Engineering and Science. All rights reserved.

\section{Corresponding Author:}

Boucetta Abd Allah,

Department of Electrical Engineering, University of Constantine 1,

Road el Bey, Constantine, 25000, Algeria.

Email: boucetta_abdallah@yahoo.com

\section{INTRODUCTION}

In recent years, the use of renewable energy resources in Algeria instead of pollutant fossil fuels has increased. Photovoltaic generation is becoming increasingly important as the most important potential in Algeria is the solar energy [1-5]. (However the cost is the most issue)

The most important of the Mediterranean basin:

- The $169.440 \mathrm{TWh} /$ year.

- 5,000 times the Algerian electricity consumption.

- 60 times the consumption of the Europe (estimated at 3,000 TWh / year) [6].

As a renewable resource and since it don't causes fuel consumption, maintenance, pollution, and emitting noise compared with other alternatives used in power applications [7]. Many countries are trying to increase the penetration of renewable energy. The US plans to reach $20 \%$ of electricity demand with solar technologies by 2030 [8].

Algeria also promised to achieve 40\% power generation from renewable energy by 2030 [9].

The principal component for connecting renewable energy sources to the grid is the power electronics interface. This interface has two main functions: conversion of direct current power to alternative current power for the grid connection and extracting the maximum power from the PV modules.

When connected to a power network, the PV systems must meet stringent power quality requirements set by the utility including low total harmonic distortion (THD) and fast dynamic response [10]. In this regard, we have studied and simulated a grid-connected power system. The system is composed of PV arrays, DC/DC boost, a three level inverter, a LC filter and a three phase grid. 


\section{POWER SYSTEM DESCRIPTION}

Because of the photovoltaic array convert solar irradiation into dc current. The dc/dc boost aim to track maximum power point of the PV system. The three-level inverter is controlled by hysteresis current control and LC filter is inserted to eliminate the harmonics contained in both the current and voltage of the inverter output.

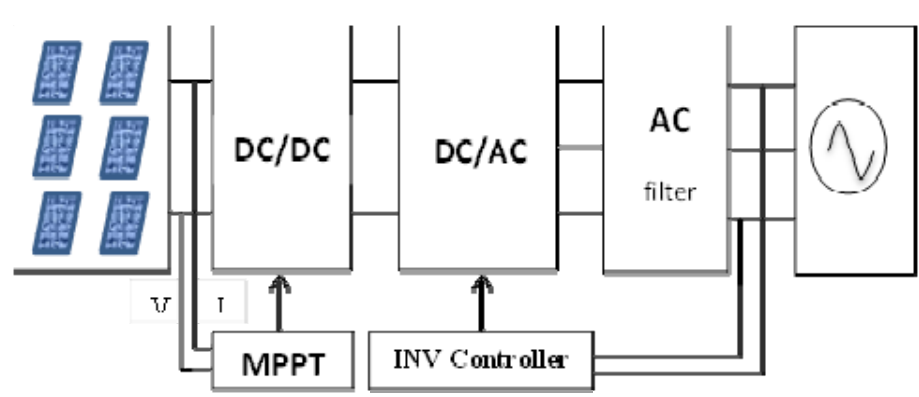

Figure 1. Diagram of grid-connected photovoltaic system with three-level inverter

\section{MODULATION}

\subsection{Photovoltaic Generator Model}

The basic unit of a PV system is the solar cell. The current and power produces by an individual solar cell typically between 1 and $2 \mathrm{~W}$ [1]. The equivalent circuit is shown in Figure 2. It is constituted of a light generated current source, a series resistance, and a parallel diode [2]. The grouped of Photovoltaic cells product a photovoltaic modules, which are combined in parallel and series to provide the desired output power.

When the number of cells in series is Ns, and the number of cells in parallel is Np, the relationship between the output current and voltage is given by:

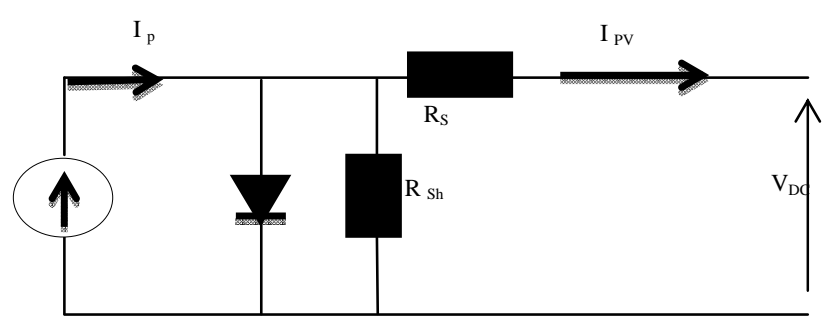

Figure 2. Circuit of a solar cell

$$
\begin{aligned}
& I_{P V}=I_{P}-I_{0}\left(\exp \left(\frac{V+R_{s} \cdot I_{P V}}{A}\right)-1\right)-\frac{V+R_{s} \cdot I_{P V}}{R_{s h}} \\
& A=n \cdot K \cdot \frac{T}{q}
\end{aligned}
$$

$\mathrm{I}_{\mathrm{pv}}$ : is the photocurrent in (A).

$\mathrm{I}_{0}$ : the diode saturation current (A).

$\mathrm{K}$ : the Boltzmann constant $1.38 \times 10^{-23} \mathrm{JK}^{-1}$.

q: the electronic charge $1.602 \times 10^{-19} \mathrm{C}$

$\mathrm{T}$ : the cell temperature $(\mathrm{K})$,

$\mathrm{n}$ : the diode ideality factor 


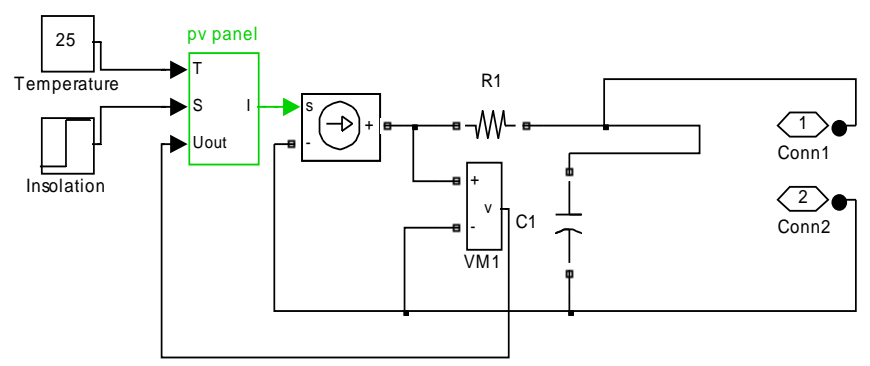

Figure 3. Simulink module of PV panel in Matlab/Simulink

\subsection{Model of the Boost DC-DC Converter}

The DC/ DC converter is used to track maximum power point of the PV system. There are two hardware topologies for MPPT, one-stage and two-stage PV systems. Because it offers an additional degree of freedom in the operation of the system, we have selected the two-stage PV energy conversion system. To reduce high frequency harmonics we have connected a capacitor between PV array and the boost circuit. The configuration of the boost circuit and its control system are illustrated in figure 4. DC-DC converters boost step-up the PV voltage to the level of the allowable maximum line voltage and to the stable required DC level without storage elements.

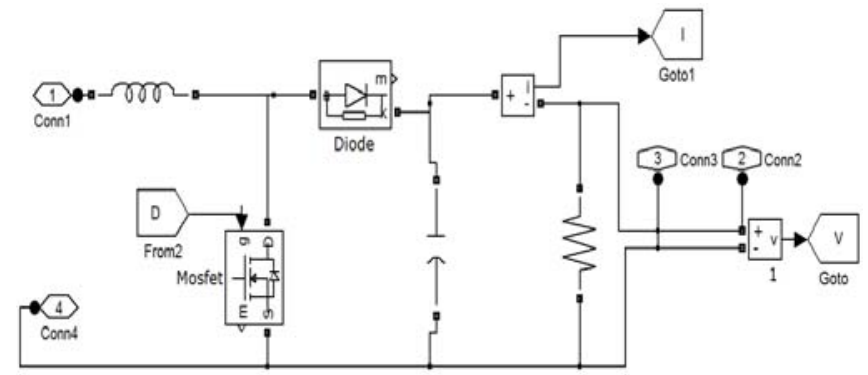

Figure 4. Simulink module of boost in Matlab/Simulink

\subsection{The Inverter}

The DC power from the PV system is converted to AC power by the inverter that we have inserted to the grid. The model for a three-phase inverter grid-connected is presented in Figure 1 which shows the power circuit of a three-phase inverter grid-connected, with IGBT switches [3]. To eliminate the harmonics contained in both current and voltage of the inverter output, an LC filter is inserted after the dc-ac inverter in order.

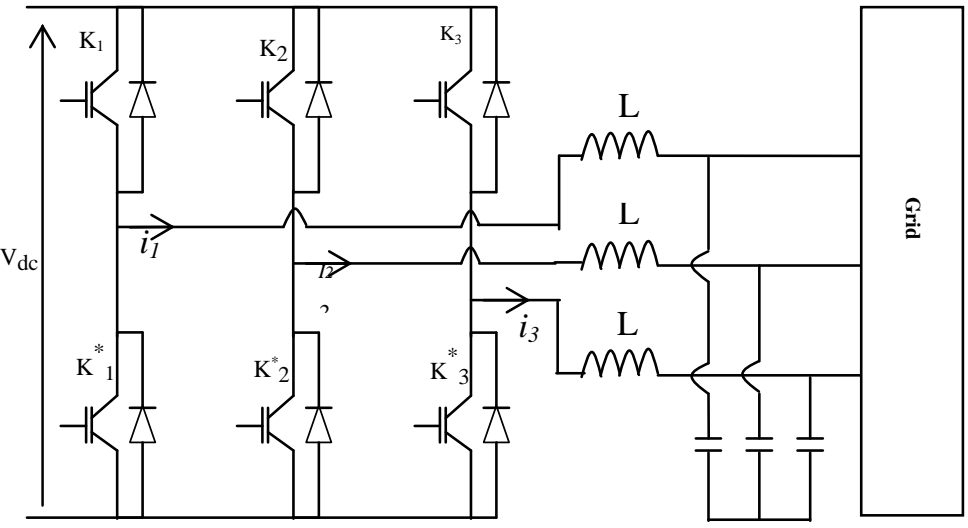

Figure 5. Schematic diagram of grid-connected three-level inverter 
Among the six switches used in the topology of Figure 1, three of them are controlled independently whereas the control of the rest is interdependent [3].

The international standards such as IEEE1547, EN61000-3-2 and IEC61727 present the standards defined by the grid authorities. According to these standards, grid interactive inverter must operate at unity harmonic components of the inverter and power factor, and the output current and/or total harmonics distortion of this current (THD\%) must be limited [4].

\section{CONTROL SYSTEM}

\subsection{MPPT}

The output voltage that corresponds to the maximum output power of the PV array varies with the voltage across the array, the irradiance and cell temperature. MPP tracking is the technique that adjusts the output voltage of the PV array in order to extract the maximum available power at any change in solar irradiation or cells temperature. There are a number of different approaches for MPPT. They are the open circuit voltage method, constant voltage method, short circuit method, perturb and observe method and the incremental conductance method [5].

\subsection{Inverter Control}

Figure 5 presented the diagram of the inverter control. The objective of the control is to regulate the input power to the grid.

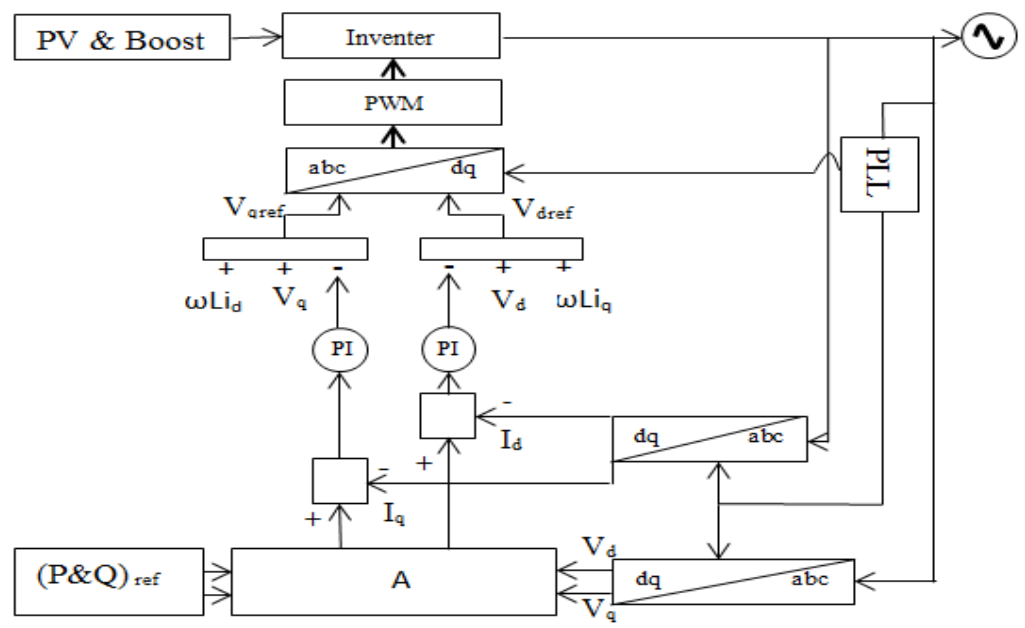

Figure 6. The block diagram of VOC with decoupling and feed forward

$$
A:\left[\begin{array}{c}
I_{d . r e f} \\
I_{q . r e f}
\end{array}\right]=\left[\begin{array}{cc}
V_{d} & V_{q} \\
V_{q} & -V_{d}
\end{array}\right]\left[\begin{array}{l}
P_{r e f} \\
Q_{r e f}
\end{array}\right]
$$

\section{SIMULATION RESULTS}

Table 1. Parameters of the grid-connected inverter

\begin{tabular}{lccc}
\hline \multicolumn{1}{c}{ Parameter } & Symbol & Value & Unit \\
\hline Grid voltage & $\mathrm{Vn}$ & 400 & $\mathrm{~V}$ \\
Grid frequency & $\mathrm{f}$ & 50 & $\mathrm{~Hz}$ \\
Filter inductance & $\mathrm{L}$ & 18 & $\mathrm{mH}$ \\
Filter capacitor & $\mathrm{C}$ & 640 & $\mathrm{mF}$ \\
\hline
\end{tabular}


The Matlab/Simulink has been used for simulating the proposed control scheme. The simulation time was set for 2.2 seconds. At the beginning of simulations, temperature and solar irradiation are supposed equal to their standard values $(250 \mathrm{C}$ and $1000 \mathrm{~W} / \mathrm{m} 2)$. Figure 7 shows that from initial conditions, the output power, voltage, current of PV array and irradiation. Figure 8 shows the current, voltage and power injected to the grid. The Simulation results of the inverter output Voltage after filtering which give a total harmonic distortion (THD) 4\% after filtering by the LC filter, This percentage is within the limits of $4 \%$ specified by the IEC. The frequency can be calculated yielding the value $50.20(\mathrm{~Hz})$. This value is within the limits of $50 \pm 1$ specified by the IEC.

Figures 9 and 10 illustrate a simulation of a step change in solar irradiation $0 \mathrm{~kW} / \mathrm{m} 2$ to $1 \mathrm{~kW} / \mathrm{m} 2$ at time $\mathrm{t}=0.5 \mathrm{~s}$. it is clearly shown that the power, voltage and current of the new MPP are rapidly reached.

The proposed single stage, three-phase three-level grid connected inverter is modeled and simulated with MATLAB/Simulink.

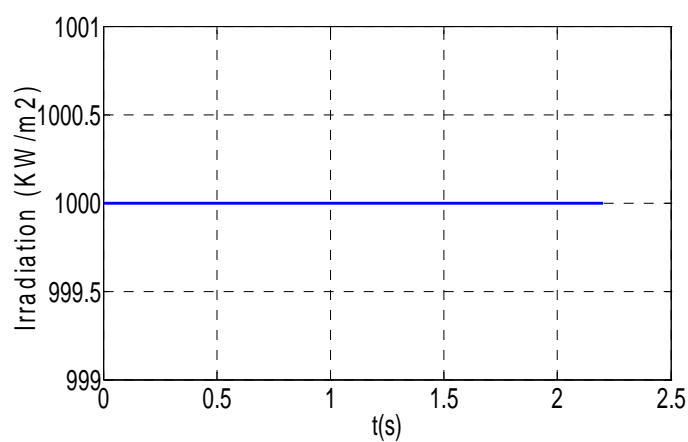

(A)

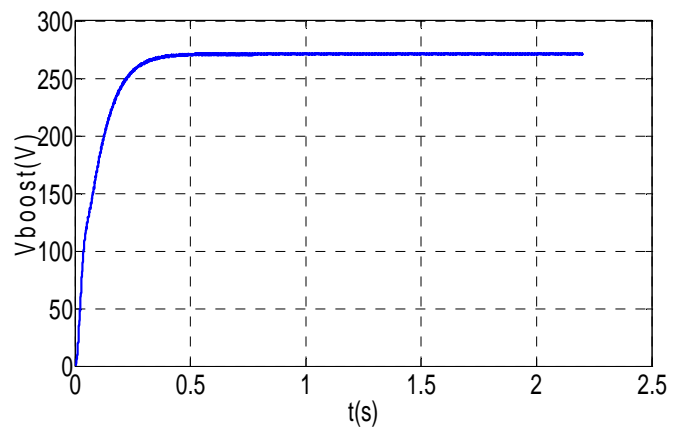

(C)

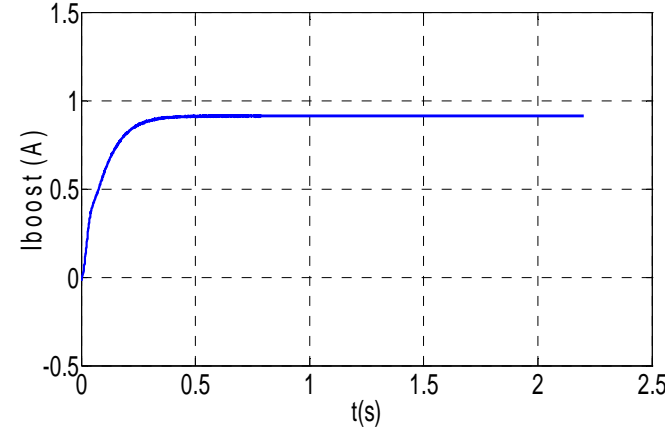

(B)

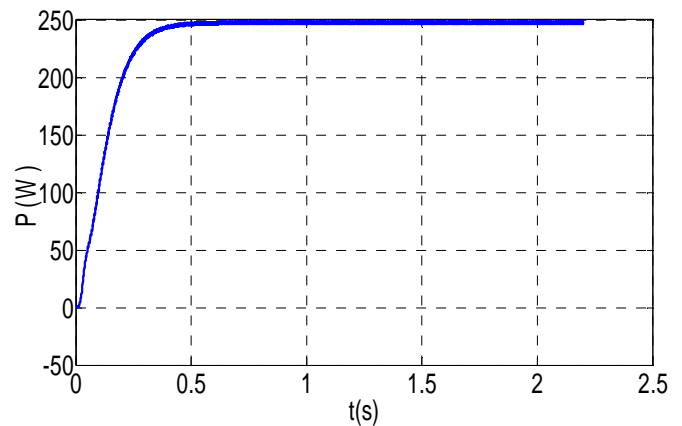

(D)

Figure 7. Irradiation PV output, current, voltage and power

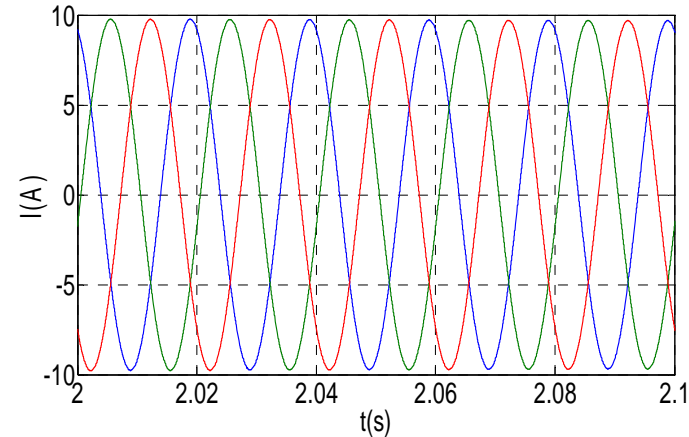

(A)

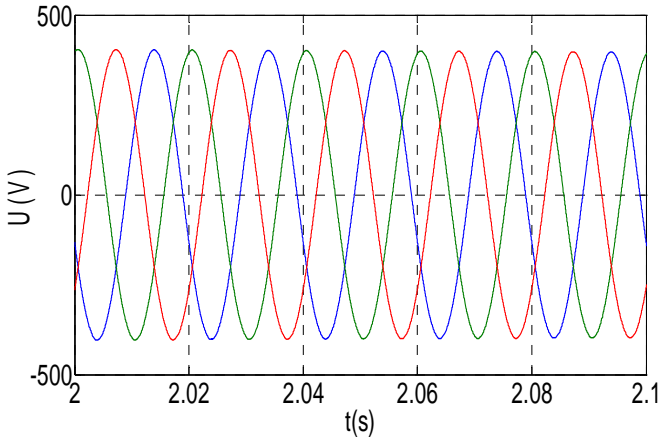

(B) 


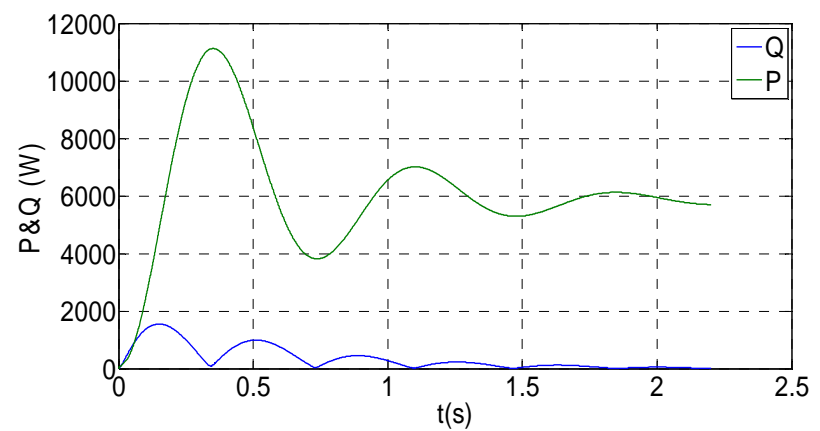

(C)

Figure 8. Curent, voltage and power injected to grid

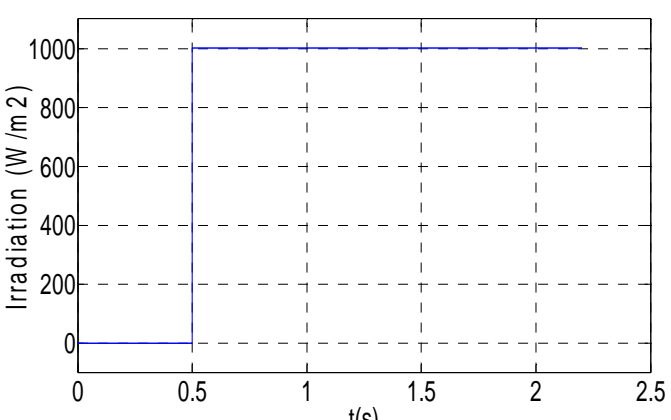

(A)

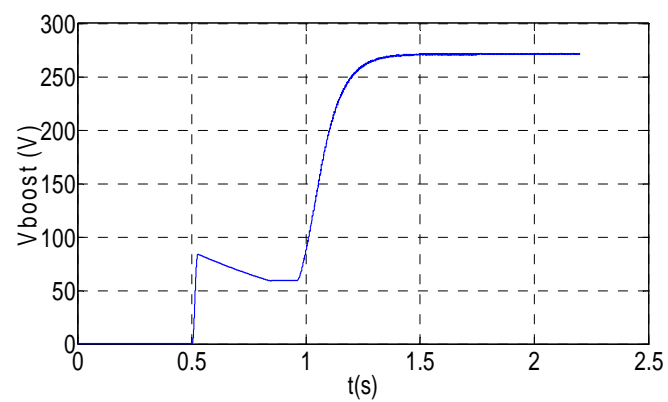

(C)

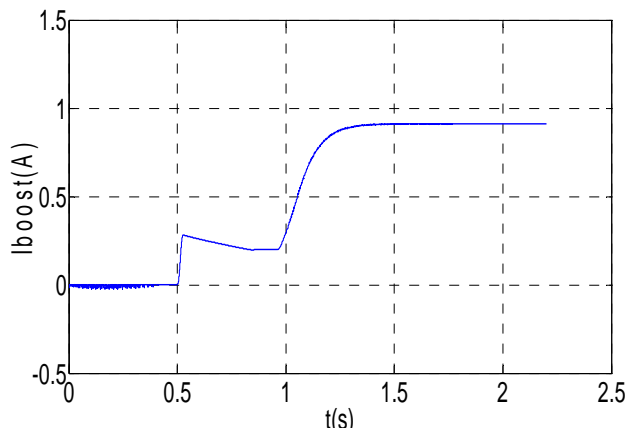

(B)

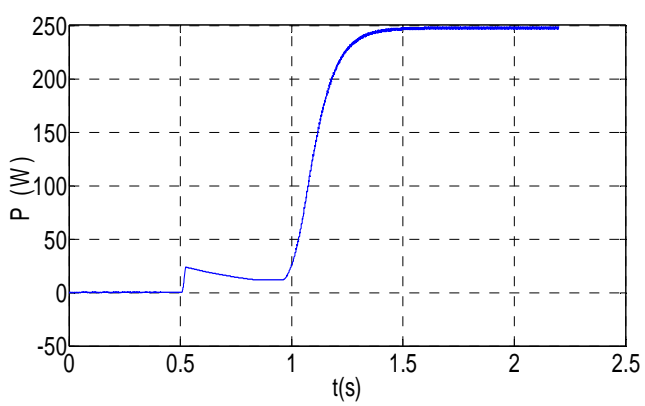

(D)

Figure 9. PV outputs behavior towards step change in solar irradiation. Irradiation, current, voltage and power

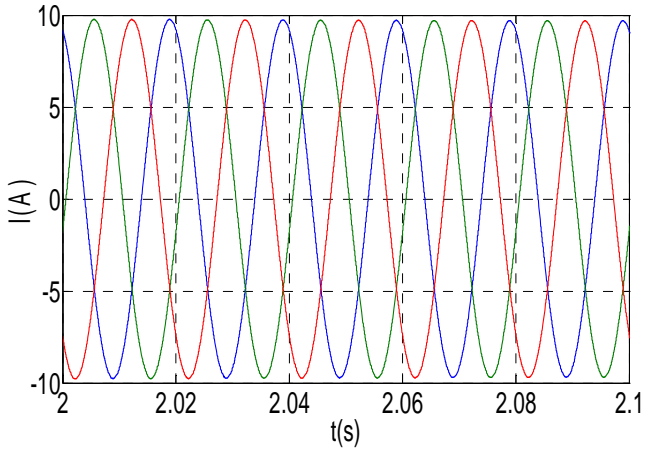

(A)

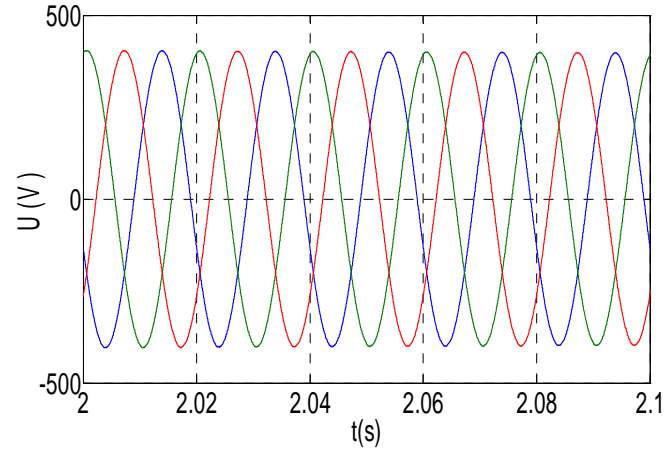

(B) 


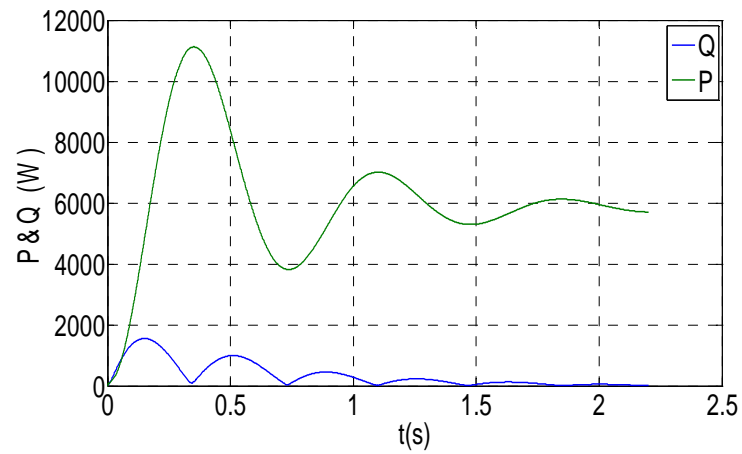

(C)

Figure 10. Current, voltage and power injected to grid after change in solar irradiation

\section{CONCLUSIONS}

To connect a photovoltaic system to grid, couple parameters have to be taking into account: the maximum power generation, control of power injected into the grid, high efficiency, and low total harmonic distortion of the currents. In this paper, the control for three-level grid-connected photovoltaic inverter has been demonstrated and simulated. Through simulation, it is observed that the system completes the maximum power point tracking, the frequency of voltage and current is within the limits specified by the IEC.

\section{REFERENCES}

[1] Miro Zeman, Photovoltaic Systems, Delft University of Technology.

[2] Djaafer Lalili $\Uparrow$, Adel Mellit 1, Nabil Lourci, Boubeker Medjahed, Chabane Boubakir, State feedback control and variable step size MPPT algorithm of three-level grid-connected photovoltaic inverter, Solar Energy, 98, (2013), 561-571.

[3] Mahdi Oloumi Baygi, Reza Ghazi, Mohammad Monfared, Applying the min-projection strategy to improve the transient Performance of the three-phase grid-connected inverter, ISA Transactions, 53, (2014), 1131-1142.

[4] Necmi Altin, Saban Ozdemir, Three-phase three-level grid interactive inverter with fuzzy logic based maximum power point tracking controller, Energy Conversion and Management, 69, (2013), 17-26.

[5] K.M. Tsang a, W.L. Chan a, X. Tang b, PLL-less single stage grid-connected photovoltaic inverter with rapid maximum power point tracking, Solar Energy, 97, (2013), 285-292.

[6] Guide to Renewable Energy’ Republic of Algeria People's Democratic Ministry of Energy and Mines, 2007 Edition Directorate New and Renewable Energies.

[7] A. Ravi a, P.S. Manoharan b,爪, J. Vijay Anand b , Modeling and simulation of three phase multilevel inverter for grid connected photovoltaic systems, Solar Energy, 85, (2011), 2811-2818.

[8] Brinkman, G., Denholm, P., Drury, E., Margolis, R., Mowers, M, Experimental assessment of the waveform distortion in grid-connected photovoltaic installations, 2011. Toward a solar-powered grid. IEEE Power Energy Mag. 9 (3), 24-32. Chicco, G., Schlabbach, J., Spertino, F, 2009. Solar Energy 83 (7), 1026-1039.

[9] Radioalgerie.dz/.../files/Energies\%20Renouvelable\%20M.\%20Rebbah.pdf

[10] Yihua Hu a, Wenping Cao b, *, Bing Ji c, Jikai Si d, Xiangping Chen, New multi-stage DC/DC converters for gridconnected photovoltaic systems, Renewable Energy 74 (2015) $247 \mathrm{e} 254$.

\section{BIOGRAPHIES OF AUTHORS}

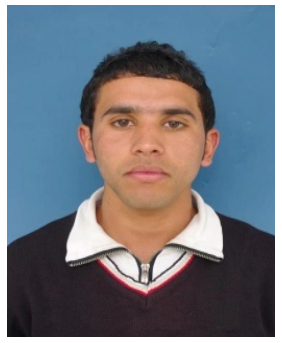

Boucetta Abd Allah: Received graduation of license in Electrical Engineering from the University of Hadje Lakhder, Batna, Algeria, in 2009. the M.S. degree in Electrical Engineering from the University of Hadje Lakhder, Batna, Algeria, in 2011, and the associate Ph.D. degree in Electrical Engineering from the University of Mentouri, Constantine, Algeria 2011. 


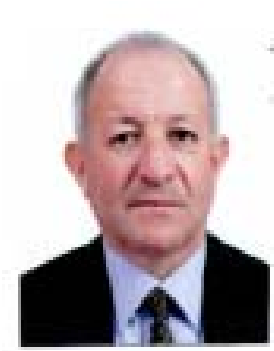

Labed Djamel: is a lecturer in the Department of Electrical of Constantine University, He received a ingenerate in Electricall from University of Annaba, a Master in Electrical Research Network from the Ecole Polytechnique of Montreal, CANADA, and a PhD in Electrical Engineering from the University Mentouri Constantine. Team leader laboratory "LGEC". His research activities focus on: Dispersed Generation; Power flow method for DC networks integrated into AC; Analysis of different types of problem quality of electric power caused by renewable energy sources; Various techniques for optimizing the optimal power flow. 